\title{
Rio Grande Basin water conservation project
}

\author{
G. Piccinni ${ }^{1}$, D. Supercinski ${ }^{2}$, D. Leskovar ${ }^{1}$, B. Harris ${ }^{2}$ \\ \& C. A. Jones ${ }^{2}$ \\ ${ }^{I}$ Texas Agricultural Experiment Station, \\ Texas A\&M Research and Extension Center, Uvalde, Texas, USA \\ ${ }^{2}$ Texas Water Resources Institute, Texas A\&M University, \\ College Station, Texas, USA
}

\begin{abstract}
The Rio Grande is 3,057 Km long with water sources from the Rocky Mountain snowmelt, the Rio Conchos in Mexico and the Pecos River in Texas. It serves as the only major source of surface water for two U.S. and five Mexican states, and supports 5 million people. The Lower Rio Grande Valley is one of the most productive agricultural areas in the U.S., generating roughly $\$ 500$ million of annual growth sales and accounting for approximately 85 percent of the region's water use. However, the population in the Basin is expected to double in the next 50 years causing doubled municipal water demands and serious agricultural impacts. The Treaty of 1906 distributed the water between Mexico and the U.S., giving 74 million $\mathrm{m}^{3}$ per year to Mexico, while the Treaty of 1944 divided the waters of the Lower Rio Grande and the Colorado River and stated the U.S. should receive 432 million $\mathrm{m}^{3}$ of water per year from Mexico over 5 year cycles. However, between 1992 and 2002, only half of the required water was delivered. The water debt grew and Mexico currently owes 81.9 million $\mathrm{m}^{3}$. The future of irrigated agriculture in the Rio Grande Valley is facing many challenges. The Rio Grande Basin Initiative is focused on helping solve these rising problems by implementing the following nine task groups: Irrigation District Studies; Irrigation Education and Training; Institutional Incentives for Efficient Water Use; On-Farm Irrigation System Management; Urban Water Conservation; Environment, Ecology and Water Quality Protection; Saline and Wastewater Management and Reuse; Basinwide Hydrology, Salinity Modeling and Technology; and Communications and Accountability. This presentation discusses the concerted results and outcomes from these tasks.

Keywords: efficient irrigation, water conservation, Rio Grande.
\end{abstract}




\section{Introduction}

Increased water demands in the Rio Grande Basin make efficient water-use and conservation a topic of utmost importance. Irrigated agriculture claims 85 percent of the region's water. The Basin's population is expected to double in the next 50 years, and thus increasing urban water demands. This rapid population growth, along with the strong agricultural industry, will further stress limited water resources already constrained by salinity and other water quality issues.

Rio Grande surface water is shared by two U.S. and five Mexican states, supporting 5 million people. Both U.S. states, Texas and New Mexico, have a similar interest in preserving the waters of the Rio Grande to meet current and future water demands.

Texas and New Mexico scientists, irrigation districts and policymakers have identified opportunities for conserving water to increase availability in the Basin. Research and educational efforts help improve the efficiency of water delivery canal infrastructure, and help both agricultural and urban irrigators use water more conservatively.

\section{The beginning of the Rio Grande Basin Initiative}

In 2001, a team of Experiment Station researchers, Cooperative Extension specialists and county agents from the Texas A\&M University System Agriculture Program and the New Mexico State University College of Agriculture and Home Economics began working with local irrigation districts and other agencies, agricultural producers, and homeowners to address these Rio Grande Basin water issues.

Funded through the U.S. Department of Agriculture Cooperative State Research, Education and Extension Service (CSREES), the Rio Grande Basin Initiative (RGBI) focuses on efficient irrigation and water conservation. CSREES funding has supported the Initiative since 2001 and continues supporting its efforts at a level of approximately $\$ 3.5$ million per year.

\subsection{Rio Grande Basin Initiative goals and objectives}

The goal of the RGBI is to meet present and future water demands through conservation measures that not only expand efficient use of available water resources, but also create new water supplies. By taking care of needed improvements in water conveyance canals and implementing more efficient irrigation systems, additional water resources will be available. Broadening outreach and teaching programs on how to efficiently utilize water resources to agricultural producers and urban water users is another objective in the water use efficiency education process.

The Texas and New Mexico Agricultural Experiment Stations and Cooperative Extension work hand in hand with other federal and state agencies, farmers, citizens and local governments to conserve water in the basin. 
To achieve these goals, the Initiative is divided up into nine task group. Each task group focuses on a specific area of concern in the region. The nine task groups are: irrigation district studies, education and training, institutional incentives; on-farm irrigation management; urban water conservation; environment, ecology and water quality protection; saline and wastewater management and water reuse; basinwide hydrology, salinity modeling and technology; and communications and accountability. Task groups conduct research, educational outreach programs and demonstrations, and strive toward significant water savings.

\section{Researchers, economists, engineers and irrigation districts}

Three of the nine tasks focus on irrigation district management, irrigation education, irrigation training and institutional incentives for efficient water use. Researchers, economists and engineers evaluate districts and infrastructure, conduct cost-benefit analyses, study policies and legalities, and conduct research and educational programs.

\subsection{Irrigation district studies}

Researchers, economists and engineers evaluate irrigation district infrastructure using Geographic Information Systems (GIS), improve canal seepage loss measurements and conduct cost-benefit analyses of proposed projects. Task members also help irrigation district managers evaluate proposed infrastructure improvements, and develop and implement a standard economic model to evaluate on-farm irrigation improvements.

Engineers have completed irrigation district maps for each Texas irrigation district along the Rio Grande. These maps will provide an indispensable tool for district modernization and rehabilitation, regional water resource analysis, and other planning efforts.

Economists have analyzed the cost of saving water and energy for rehabilitation projects throughout the Lower Rio Grande Valley. Initial calculations show that about $\$ 200$ million in investments will provide 260.3 million $\mathrm{m}^{3}$ of water savings a year from the water delivery infrastructure in the area.

Researchers estimated seepage losses from 10 to 30 percent of the total amount of water delivered in El Paso's Franklin Canal. Ponding results show water seepage rates from $123,750 \mathrm{~m}^{3}$ to $479,000 \mathrm{~m}^{3}$ per $\mathrm{Km}$ along the canal. Losses along the Westside Canal measure $309,000 \mathrm{~m}^{3}$ to $617,000 \mathrm{~m}^{3}$ per $\mathrm{Km}$.

\subsubsection{Irrigation education and training}

Researchers and engineers evaluate and demonstrate minimum performance standards for irrigation systems, and train private and commercial irrigators on improved methods and systems. They also conduct research and extension educational programs to help convey information more easily to the public. 
A project called User Friendly Drip Irrigation and Mulch Systems for Urban Specialty Crop Production, aimed at increasing the use of drip irrigation and mulch systems for urban specialty crops, has helped New Mexico Master Gardener cooperators to reduce water application by 29.3 percent.

Engineers have teamed with the San Antonio Water System and the Texas Turf Irrigation Association to complete a detailed irrigation system design. The design will be used as a public service project to rehabilitate the irrigation systems of the San Antonio Botanical Gardens.

3.1.1.1 Institutional incentives for efficient water use Efforts of this task are focused on identifying legal and institutional barriers that limit water conservation; analyzing impacts of alternative water management and incentive policies; and developing an electronic database of historical irrigated acreage in the Rio Grande Basin.

"Database Recommendations for Irrigation Districts" reports are available, which offer irrigation districts suggestions for better GIS and data management integration. The upgraded database will allow easier incorporation with software tools and facilitate the use of data to make management operational decisions.

Engineers assisted the City of Brownsville, Texas with justification of an onfarm water metering program that will result in an estimated water savings of 104 million $\mathrm{m}^{3}$ per year. Technical assistance such as this has saved districts $\$$ 1.8 million in the cost of hiring consultants.

Researchers in El Paso, Texas have teamed with New Mexico State University and Siena College researchers to collaborate on integrated economic, institutional and hydrologic models to be used to study the Upper Rio Grande Basin. Initial research shows drought losses could be reduced by 20 to 30 percent.

\section{On-farm and urban conservation and management}

Due to the expected doubling of the Rio Grande Basin's population, water conservation is one of the most important measures that can be taken to ensure water availability for current and future demands. On-farm irrigation management and urban water conservation are the next two tasks which both focus on this particular issue.

\subsection{On-farm irrigation system management}

Researchers and extension personnel demonstrate improved irrigation scheduling to optimize crop growth, yield and quality while conserving water. They develop water conservation strategies for flood, microspray and drip irrigation systems, and they assess the costs and benefits of water management systems. Crop production models and decision support systems (DSS) are also adapted for irrigated agriculture.

Information on how much water can be saved by adopting on-farm water conservation technologies is scarce due to a lack of accurate records of crop 
water-use. This information is required for improved irrigation scheduling to reduce water inputs and losses. Researchers are working with in-ground monolithic weighing lysimeters to determine phenologically specific crop coefficients (Kc) of crops grown in the Rio Grande Basin. These Kc are then used for calculating crop water-use for crops grown in each region of the basin utilizing a network of weather stations. Furthermore, research and extension specialists demonstrate decision support systems such as PET and the CroPMan model to improve real-time water management, maximize production and profit, increase irrigation efficiency and identify limitations to crop yield. Extension agents coordinate demonstration activities with sugarcane, corn, sorghum and cotton research programs in the Lower Rio Grande Valley

Water is the primary factor limiting production of sugarcane in the Lower Rio Grande Valley of Texas. A research project is providing improved understanding of crop water-use by sugarcane. This results in better recommendations for irrigation of sugarcane which increase yields while using less water. Water savings of up to 30 percent could be achieved with overhead sprinkler or drip irrigation, but the cost of such systems has limited their acceptance. The 18,000 hectares of sugarcane grown in the Lower Rio Grande Valley of Texas in 2005 required roughly 247 million $\mathrm{m}^{3}$ of irrigation water to produce. Use of improved furrow irrigation techniques and scheduling developed based on the results of this project would save 10 to 15 percent of this irrigation water, or between 25 and 37 million $\mathrm{m}^{3}$.

Conservation tillage is becoming increasingly popular compared to conventional tillage for row crop production for various reasons, including reduced costs and long-term improvement in soil properties. Better water-use efficiency should result from reduction of losses caused by tillage as well as improvement in water retention as soil properties, including organic matter content, improve. In a subtropical environment, however, such benefits are proving to be difficult to obtain. Water savings by reductions in tillage can be lost depending on the timing of rainfall. Cover crops to improve soil properties require more water to produce. Crop residues decompose quickly in a subtropical environment making it difficult to build up water retaining organic matter. While conservation tillage offers distinct advantages for producers, it has thus far been difficult to show water savings that can contribute to this advantage.

Our research with onion production in the Lower Rio Grande Valley indicates that a substantial amount of water could be saved by using subsurface drip irrigation instead of furrow irrigation. These water savings were obtained without compromising productivity. This translates to nearly 10 million $\mathrm{m}^{3}$ of potential water savings in onion production for the Lower Rio Grande Valley given that only about 10 percent of the 5,000 ha of onions currently grown in the Valley are drip irrigated.

Volumetric monitoring of on-farm water-use provides the most accurate means for documenting on-farm water-use, fine-tuning irrigation scheduling and quantifying the success of water conservation when best management practices are implemented. Volumetric flow-metering, when used in conjunction with other water conserving strategies, can increase growers' profit margins by 
reducing production costs. There are roughly 40,000 ha of highly-value, mostly furrow-irrigated vegetable crops grown in the Valley. Converting from furrow to drip irrigation of major vegetables grown in the Valley could conserve a significant amount of water and actually increase productivity and the competitiveness of the industry.

The evaluation of drip, microjet spray and flood irrigation practices in citrus under the on-farm irrigation task project has resulted in increased dollars from the State of Texas to monitor water-use and water conservation practices in the Lower Rio Grande Valley. Documented water savings as a result of these onfarm water conservation studies led to the acceptance of a larger proposal to assess water use in citrus and other horticultural crops in the Rio Grande Basin. In February 2005, the Texas Water Development Board provided funding to assess long-term (2005-2014) water-use in citrus and vegetable production in the Lower Rio Grande Valley under the direction of the Harlingen Irrigation District, Texas A\&M University and Texas A\&M University-Kingsville. The information gathered from ADI (Agricultural water conservation Demonstration Initiative) on-farm demonstration projects will further evaluate low-water-use systems like drip and microjet spray irrigation, and varying flood irrigation practices. These demonstration sites consist of water conservation on farm-scale land areas ranging from 5 to 25 ha each. The ADI funding will couple well with the scientific research studies being performed on smaller areas under the RGBI onfarm water conservation work in citrus. The combination of research and demonstration sites on grower's fields will provide a great baseline of information regarding overall water-use in the Rio Grande Basin and will provide answers on how to address improved water-use while maintaining good agricultural production in the Valley.

Through the RGBI, impacts of efficient water conservation practices using subsurface drip irrigation and center pivot systems on economically important vegetable crops have been confirmed in the region. Researchers have been focusing on spinach, onions, watermelon, artichoke and several varieties of peppers to evaluate and develop deficit irrigation practices. These practices also include different plant populations and nitrogen fertilization rates, which is environmentally important for the soil and groundwater resources. In collaboration with local partner agencies and industries, an increased interest is being placed in large-scale evaluations of the less expensive low-pressure drip system (LPS) which is being considered to be incorporated into the United States Department of Agriculture Cost Share Programs.

Outcomes from these experiments are educating many "progressive farmers" in water conservation practices. Data from research experiments are being used in pilot studies in growers' fields to demonstrate the ability to save a minimum of 25 percent of the normal crop water requirements without depleting yields. Furthermore, the Precision Irrigators Network (PIN) is including the growers in the research process. This way of conducting research allows the growers to take ownership of the research findings a lot quicker than if the research was conducted in another location and the results delivered to the growers. From the results of our study we estimated that on a "typical" 50 ha field with a fall 
vegetable rotated by a summer row crop, water savings can amount to 150 to 200 $\mathrm{mm}$ of water per ha per year or 380 to 510 million $\mathrm{m}^{3}$ of water per year based on 251,000 ha of irrigated land in the Rio Grande region alone.

\subsubsection{Urban water conservation}

Conserving water through improved landscape ordinances, designs and irrigation systems are just a few of the methods demonstrated in this task. Guidelines are developed for urban water conservation, salt-tolerant plant varieties are identified, and the use of brackish wastewater for irrigation is demonstrated. Inhome water conservation studies have also been conducted to reduce the amount of water families use on an everyday basis.

Extension housing specialists conducted a water conservation study to determine how much a family of four can reduce its water consumption over a three-month period by installing water saving toilets, showerheads and faucet aerators. Fifteen families from five counties participated in this study, and at the study's conclusion the 15 households had a total combined water savings valued at approximately $\$ 4,900$.

Some 91,000 to $129,000 \mathrm{~m}^{3}$ of water could be salvaged each year if homeowners practiced landscape water conservation. More than 800 homes were surveyed in Weslaco and 51 percent were found to be using excess water for landscape irrigation. By using monthly water budgets based on landscape size, potential evapotranspiration value and landscape coefficients, homeowners could reduce their landscape irrigation water-use by 48 percent annually.

Many turf managers throughout New Mexico are making plans to convert to the water-saving application of sub-irrigation. Research conducted at New Mexico State University shows a dramatic potential water savings of 80 percent.

\section{Water quality protection, environment, salinity and reuse}

The environment is yet another important component to consider when dealing with the Rio Grande. Ecology and water quality are vital elements that need to be studied in order to preserve and protect the Rio Grande. Salinity in the water can also be a major water quality problem for irrigators as well as homeowners. Both wastewater management and reuse are focused on through the next two tasks.

\subsection{Environment, ecology and water quality protection}

Several measures are taken to ensure that the Rio Grande's surrounding environment and its water quality are protected. Screening private water supplies for purity, demonstrating how soil testing can help protect water quality and quantity, and demonstrating control of invasive aquatic weeds are a few examples of efforts taken on by researchers and extension specialists involved in this task. Analyzing the Rio Grande's water for the presence of pathogens that could pollute irrigation water is an important ecological measure taken. Saltcedar along the river is another major concern because of the amounts of water these invasive trees take away from the river. Therefore, determining how much water 
can be salvaged by saltcedar controls is a top priority in this task area. Increasing water-use efficiency and reducing erosion on rangeland are equally important.

The Pecos River in Texas is one of the main sources of water that flows into the Rio Grande, however more than 50 percent of the $670 \mathrm{Km}$ of the Pecos River are infested with saltcedar. Efforts are under way to treat this saltcedar infestation through the Pecos River Ecosystem Project. More than 1,200 ha of saltcedar were treated and removed in 2003 along the Pecos and its tributaries.

Researchers have determined exactly how much Cryptosporidium and Giardia are present in river water after release from wastewater treatment plants along the Rio Grande. Genetic typing is also under way to determine the human or animal source of the detected pathogens so potential risks to humans can be assessed.

\subsubsection{Saline and wastewater management and reuse}

Researchers demonstrate the use of treated wastewater and brackish water for irrigation as an alternate water source to further conserve the waters of the Rio Grande. Extension educators train homeowners to install septic systems and implement self-help programs for wastewater treatment in "colonias" (generally, sub-standard construction outside of municipal services) in an effort to reuse the water and provide another water resource.

Extension specialists have conducted several short courses on basic and advanced on-site wastewater treatment for homeowners, and spray distribution of effluent and high strength wastewater for practitioners in areas along the Rio Grande. Fact sheets, presentations and demonstrations about rainwater harvesting, graywater, subsurface drip distribution fields and wastewater treatment have also been developed.

Researchers have studied the plant-salt-tolerance relationship for different species of plants, providing guidelines for use of a specific amount of saline irrigation on different plant varieties. Tolerant plants can tolerate up to 10,000 parts per million (ppm) of dissolved salts without suffering. Sensitive plants can only take up to $1,000 \mathrm{ppm}$. Research is still under way to develop management practices to reduce overall saline content in soil and irrigation water.

Reclaimed wastewater is a major contributor to both urban and agricultural landscapes in the El Paso area. Reclaimed wastewater is about 60 to 90 percent of the cost of potable water supplies. Emphasis has been placed on the detection of contaminants in these water sources. By using phytoremediation treatment, $\$$ 120 per cubic meter can be saved. This will also help extend existing water supplies, ensure food safety and quality, create a safe and reliable water supply, and develop sustainable agronomic strategies to utilize reclaimed waters.

\section{Modeling, technology and communications}

Technology plays a major role in everything today, and the RGBI project is no exception. The last two tasks both involve the use of modern technology in one form or another. 


\subsection{Basinwide hydrology, salinity modeling and technology}

Task researchers and extension specialists cooperate with the Texas State University System, New Mexico State University, and other state and federal agencies to develop GIS-based historical and resource databases. They also develop coordinated, basinwide hydrology and water quality modeling efforts.

Natural resource data has been collected for counties along the Rio Grande and organized into spatial databases that provide GIS coverage for a particular county. To date, 16 Texas counties have been analyzed and mapped. Stakeholders can access and identify environmental, natural resource and socioeconomic information for each county. Data for additional counties has been collected and processed for Web hosting.

A Coordinated Water Resources Database and GIS Web site has been created to collect, synchronize and provide timely online access to flow and waterquality data for use by stakeholders, scientists, water agencies and irrigation districts. By effectively and efficiently monitoring and operating the passage of Rio Grande flows and water quality in the region, water quality can be maintained within acceptable limits for effective water treatment, especially during low-flow periods.

\subsubsection{Communications and accountability}

Providing project oversight, communications support and accountability are key elements in this project as a whole. Members of this task group report program outcomes and results of collaboration among scientists, extension specialists, institutions, agencies, and urban and agricultural clientele. They ensure timely communication of outcomes and impacts to various audiences through reports, feature stories, newsletters, conferences and electronic media. This is the group responsible for "getting the word out" about the project's accomplishments and noteworthy news. They collect project information and reports, keep them on file and compile an annual booklet with all accomplishments and outcomes listed under each task group.

Quarterly, the Rio Grande Basin Initiative Outcomes newsletter is distributed to project participants and other interested parties to communicate recent accomplishments, water savings and other project information. News and feature stories are written throughout the year as well and are posted on the Rio Grande Basin Initiative Web site (http://riogrande.tamu.edu) so they are accessible to everyone at any time. These communications materials allow project participants to stay involved and up-to-date with the activities of other tasks and project members.

Communications and accountability helps hold everyone together and keeps everything on track - making each person responsible for the efforts and work to which they were assigned. Communication plays a key role in keeping everyone well-informed of the activities of other task members and project participants, as well as recognizing individuals for their own project accomplishments. 


\section{Conclusion}

RGBI efforts and activities have greatly impacted the region as well as the waters of the Rio Grande. Millions of dollars have been saved due to new technologies and irrigation and conservation methods being implemented in the area. Millions of $\mathrm{m}^{3}$ of water have been saved through these methods as well.

Visible improvements have been made to the canal infrastructure - building new infrastructures and replacing or renovating canal gates, linings and other canal equipment and infrastructure. A new understanding of methods for saving water is now available to growers, urban water-users and stakeholders. These results are made possible by a concerted effort of several scientists, extension specialists and agents, and communication specialists. Furthermore this project overcomes interagency barriers using the best possible resources available at various institutions.

As a final note, the success of this project needs to be attributed equally to the all the people that participate in it. They are: Naomi Assadian, Red Baker, Max Bleiweiss, Chris Braden, Raul Cabrera, David Cowley, Bobby Creel, Leeann DeMouche, George Dickerson, George DiGiovanni, Monty Dozier, Keith Duncan, Juan Enciso, Mike English, Connie Falk, Sam Fernald, Guy Fipps, Robert Flynn Tom Gerik, Steve Guldan, Ereney Hadjigeorgalis, Bill Harris, Janie Harris, Charles Hart, Woods Houghton, Brian Hurd, Jennifer Jacobs, John Jifon, Allan Jones, Ron Kaiser, Phillip King, Connie Kratzer, Ron Lacewell, Eric Leigh, Bernd Leinauer, Bruce Lesikar, Daniel Leskovar, Gino Lujan, Wayne Mackay, Michael Masser, Alyson McDonald, Mark McFarland, Denise McWilliams, John Mexal, Mike Mecke, Ari Michelsen, Seiichi Miyamoto, Mark Muegge, Shad Nelson, Genhua Niu, Keith Owens, Geno Picchioni, Giovanni Piccinni, Ed Rister, Craig Runyan, Rossana Sallenave, Zohrab Samani, Ted Sammis, Bob Sanderson, Jill Schroeder, Barak Shemai, Zhuping Sheng, Erin Silva, Val Silvy, Rhonda Skaggs, Curtis Smith, Raghavan Srinivasan, Tamaron Stewart, Rolston St. Hilaire, Allen Sturdivant, Danielle Supercinski, Jaclyn Tech, David Thompson, April Ulery, Frank Ward, Ellen Weichert, John White, Richard White, and Bob Wiedenfeld.

Some of RGBI's key collaborators include: Texas Water Resources Institute, Texas Agricultural Experiment Station, Texas Cooperative Extension, New Mexico Cooperative Extension, NMSU Agricultural Experiment Station, NMSU Water Task Force, USDA Natural Resources Conservation Service, U.S. Bureau of Reclamation, U.S. Geological Survey, Regional Water Planning Groups, Texas Department of Agriculture, Texas Water Development Board, irrigation districts, commodity organizations, North American Development Bank, Border Environmental Conservation Commission, selected consultants, International Boundary and Water Commission, and the Lower Rio Grande Development Council.

This material is based upon work supported by the Cooperative State Research, Education and Extension Service, U.S. Department of Agriculture under Agreement No. 2005-34461-15661 and Agreement No. 2005-4504903209. 